\title{
Divergent memories and visions of the future in conflicts over mining development
}

\author{
Erik Kojola ${ }^{1}$
}

Texas Christian University, USA

\begin{abstract}
Conflicts over extractive development often center around predicting future profits and economic growth, and estimating industrial pollution. How these projections are understood and seen as legitimate and trustworthy depends on social actors' environmental imaginaries and timescapes. Thus, I examine the temporal and cultural dynamics of natural resource politics, particularly how affective connections to the past and future mobilize support and opposition to new mining. I use the case of proposed copper mines in the rural Minnesota Iron Range region to explore the different environmental imaginaries and timescapes that mining opponents and proponents use to understand the potential socio-environmental impacts, and to legitimate their positions. Proponents, including long-time and working class Iron Range residents and mining corporations, view the region as an industrial landscape built by mining and hope new proposals will renew the past to create a prosperous future. Meanwhile, environmental groups who oppose mining view the region through an environmental imaginary based on outdoor recreation, and draw on collective memories of family and youth trips to understand new extractive projects as a rupture to their vision of the future. I show that resource extraction is understood through temporalities that differ across intersections of class and region, and that emotional meanings of the past and visions of the future animate contemporary political action.
\end{abstract}

Keywords: Resource extraction, mining, environmental imaginaries, timescapes, collective memory, environmental politics, emotions

\section{Résumé}

Les conflits sur l'extraction des ressources sont souvent centrés sur la prévision des bénéfices futurs et la croissance économique, et sur l'estimation de la pollution. La manière dont ces projections sont comprises et considérées comme légitimes et dignes de confiance dépend des imaginaires environnementaux et des paysages temporels des acteurs sociaux. Ainsi, j'examine les enjeux temporels et culturels de la politique des ressources naturelles, en particulier la manière dont les liens affectifs avec le passé et le futur mobilisent le soutien et l'opposition aux nouvelles activités minières. Le cas des mines de cuivre proposées dans la région rurale du « Minnesota Iron Range » montre les différents imaginaires environnementaux et temporels que les opposants et les promoteurs de l'exploitation minière utilisent pour comprendre les impacts et légitimer leurs positions. Les partisans, y compris les résidents de longue date, la classe ouvrière et les sociétés minières, considèrent la région comme un paysage industriel construit par l'exploitation minière et ils espèrent que de nouvelles propositions renouvelleront le passé pour créer un avenir prospère. En revanche, les groupes environnementaux maintiennent un « imaginaire environnemental» basé sur les loisirs de plein air, et ils conservent des souvenirs collectifs des voyages de la famille et des jeunes dans la région. Ils considèrent les nouveaux projets extractifs comme une rupture de leur vision du futur. Je montre que l'extraction des ressources est comprise à travers certaines temporalités qui varient selon les intersections de classe et de région. Les significations émotionnelles du passé et les visions du futur animent l'action politique contemporaine.

\footnotetext{
${ }^{1}$ Dr. Erik Kojola, Assistant Professor, Department of Sociology and Anthropology, Texas Christian University, TCU Box 298710, Fort Worth, TX 76129, USA. Email: e.kojola "at" tcu.edu. The author would like to acknowledge the anonymous reviewers and editor for their insightful and helpful comments on the article, and Dr. Ashley Fent in helping prepare the Special Section. This is the fourth article in Ashley Fent and Erik Kojola (eds.). 2020. "Political Ecologies of Time and Temporality in Resource Extraction", Special Section of the Journal of Political Ecology 27: 819-938.
} 
Mots clés: extraction de ressources, exploitation minière, imaginaires environnementaux, paysages temporels, mémoire collective, politique environnementale, émotions

\section{Resumen}

Los conflictos generados por el desarrollo extractivista normalmente se centran en la predicción de la rentabilidad y el desarrollo económico, así como en las estimaciones de la contaminación industrial. Cómo estas proyecciones son entendidas y vistas como algo legítimo y confiable, depende de los imaginarios ambientales y paisajes temporales de los actores sociales. Por ende, me enfoco en examinar las dinámicas temporal y cultural de las políticas de recursos naturales, particularmente cómo conexiones afectivas con el pasado y el futuro movilizan el apoyo y la oposición a nuevos proyectos mineros. Utilizo el caso de los proyectos de las minas en la región Iron Range, en Minnesota rural, para así explorar los diferentes imaginarios ambientales y paisajes temporales que opositores y defensores de la minería utilizan para entender los potenciales impactos socioambientales y legitimar sus posturas. Quienes defienden los proyectos, incluídos los antiguos residentes y la clase trabajadora de Iron Range, así como las corporaciones mineras, ven a esta región como un paisaje industrial edificado por la minería y esperan que las nuevas propuestas renueven el pasado para crear un futuro próspero. Al mismo tiempo, los grupos ambientalistas que se oponen a la minería ven a la región a través de un imaginario del medio ambiente basado en las actividades al aire libre y lo fundamentan con memorias colectivas de viajes familiares y de juventud. Así, estos actores entienden los nuevos proyectos extractivistas como una ruptura de su visión acerca del futuro. Además, demuestro cómo la extracción de recursos es entendida a través de temporalidades que difieren a lo largo de las intersecciones de clase y región, y que, la importancia emocional del pasado y las visiones del futuro impulsan la acción política contemporánea.

Palabras clave: extracción recursos, minería, imaginarios ambientales, paisajes temporales, memoria colectiva, política ambiental, emociones

\section{Introduction}

Decisions about where, how, or whether to develop new resource extraction sites depends on how potential environmental impacts and economic benefits are assessed. Predictions of economic growth and environmental risks are used to weigh costs and benefits, and to evaluate the future impacts of mining. While forecasts of environmental and economic impacts by corporations and government agencies are often presented as apolitical technical calculations, political ecology and STS scholarship argues they are produced through power and culture, and based on political and normative assumptions about an ideal future (Donovan and Oppenheimer 2015; Goldman, Nadasdy and Turner 2011; Jasanoff and Kim 2015; Kinchy 2012; Spiegel 2017). Thus, decisions about extractive development are conflicts between divergent environmental imaginaries constructed through cultural frameworks for understanding the past and the future. Corporations often legitimize extractive development by constructing visions of an abundant future and romantic memories of a mining heyday while residents interpret new projects through their collective memories of industry (Kneas 2016; Roberts 2008; Wheeler 2014). Meanwhile, mining opponents often mobilize resistance through alternative predictions of pollution and, imaginaries of a cleaner future without extractive industries (Horowitz 2010; Nesbitt and Weiner 2001; Spiegel 2017). Therefore, temporality is a key dynamic in natural resource politics as groups struggle over representations of the past and visions for the future (Mathews and Barnes 2016; Peet and Watts 1996).

In this article I study the Northern Minnesota Iron Range - an emblematic rural mining region and one of the world's largest suppliers of iron ore - to explore the temporal dynamics of the politics of natural resources and prognosis (Mathews and Barnes 2016). Over the past decade, multinational mining companies have been exploring a new type of mining, copper and other nonferrous metal mining, which would be riskier than existing iron (ferrous metal) extraction. The additional risks are due to the geochemistry of copper ores that can generate acids and leach heavy metals when exposed to air and water, and the potential impacts on ecologically and socially important waterways. The projects also raise the possibility of creating jobs and economic development in a rural region facing unemployment and population loss. Thus, copper mining has become a major political issue in Minnesota with mobilization by supporters and opponents. It is a symbolic struggle over the region's past, present, and future. 
This article makes two main contributions to political ecology scholarship. First, I build on growing political ecology research on temporality and resource extraction (Burnham et al. 2017; Ferry and Limbert 2008; Li 2014, 2017; Weszkalnys 2014; White 2017) by using the concepts of environmental imaginaries and timescapes to emphasize the cultural and temporal processes in conflicts over producing natural resources. I conceptualize environmental imaginaries as temporal and constructed through understandings of the past and future by drawing on theories of timescapes and collective memory (High and Lewis 2007; Hodgkin and Radstone 2003; Lipsitz 1990; Radstone and Hodgkin 2003). I interrogate how the past and future are understood across the social locations of class, region, and gender and how they are constructed in relation to nonhuman nature.

Second, I use theories of emotional politics and nostalgia (Bonnett 2016; Mukta and Hardiman 2000; Norgaard 2011; Raynes et al. 2016; Scott 2013; Threadgold et al. 2018) to argue that the affective meanings of time in environmental imaginaries animate conflicts over extractive industries. I show how emotions of nostalgia and hope drive mobilization, and shape the different ways that social actors interpret predictions of job creation and environmental risks and legitimate their positions. Nostalgia is not inherently reactionary or progressive as it motivates opposition and support for capitalist resource extraction.

In the following section I provide background on the Iron Range, and conflicts over copper mining development. The next section discusses theoretical perspectives related to political ecology, environmental imaginaries, timescapes, and emotion. Then I apply these approaches in my analysis section and conclude with some broader reflections and suggestions.

\section{Background: the Minnesota Iron Range and copper mining}

The Iron Range is indicative of extractive regions that are often remote and isolated, have an economically and politically dominant mining industry, experience boom and bust cycles, and have a strong community identity. The Iron Range is a geographic area defined by several mineral complexes, particularly large iron deposits, in the Northeastern corner of Minnesota near the Canadian border (Figure 1). The region covers roughly 100 miles $(161 \mathrm{~km})$ from Grand Rapids, $\mathrm{MN}$ in the southwest to Ely, $\mathrm{MN}$ in the northeast. Iron mining began in the late $19^{\text {th }}$ century and the area became one of the world's largest producers of iron (Manuel 2015). The Iron Range is also a socio-cultural region shaped by this extractive history and the formation of mining towns with a regional identity of being "Rangers." The Ranger identity is shaped by histories of immigration from Eastern Europeans, Italians, and Scandinavians who came to the region for jobs in mining and logging and formed tight-knit immigrant enclaves that lasted for multiple generations (Hemphill 2005). This regional identity is constructed through cultural narratives about surviving in the harsh climate and isolated place, which contributes to a sense of pride and solidarity (Backes 1991; Manuel 2015).

The Iron Range is also near popular outdoor recreation areas and many lakes and rivers. Conflicts over environmental conservation also shape the region's history. The northern and eastern edge of the Iron Range abuts state and national forests, including the Boundary Waters Canoe Area Wilderness (BWCAW) which is one of the most visited wilderness areas in the U.S. and popular for canoeing and fishing (Lavanger 2018). The BWCAW is a cherished and contested place that has long been at the center of struggles between resource extraction and environmental conservation. Since the 1930s there has been conflict over how the land and water is used, including over limits on logging and mining. Many local residents opposed creating a federally protected wilderness area in the 1960s, but the effort galvanized wilderness and conservation supporters in Northern Minnesota and around the state and nation (Proescholdt, Rapson and Heinselman 1995).

The Iron Range has experienced job loss and population decline over the past 50 years due mechanization of iron mining and fluctuations in the global steel industry (Manuel 2015). In 2016 there were around 4,500 iron mining jobs, down from a peak of 16,000 jobs in 1979 (Kraker 2016). The remaining jobs are coveted because they provide good pay, benefits, and union protections. Despite the regional economy increasingly being led by services, education, and healthcare, mining remains politically, culturally, and economically powerful.

The town of Ely (Figure 1) embodies the tensions between extractive and outdoor recreation histories, and mining boom and bust. The town was formed in the late 1800s to house workers for iron mines (Lamppa 
2004). Yet, the iron ore operations closed in 1967 which left the town without a mine and people without jobs, although some workers stayed in Ely and commuted to other iron mines 50-70 miles (80-112 km) away (Hillman 2007). As iron mining declined, the town became the gateway to the BWCAW and developed a tourism and hospitality industry. In the past 30 years, more people have relocated to Ely and surrounding areas to retire near outdoor amenities or to work in the tourism industry, in which employment grew $1.4 \%$ yearly from 2012 to 2016 (Stock and Bradt 2018). Still, the town's population of 3,376 in 2017 was below its peak in the 1930s, and school enrollment has dropped by a third since the 1960s when the last mine closed, to about 6,000 (Forgrave 2017; Lamppa 2004; U.S. Census Bureau 2018).

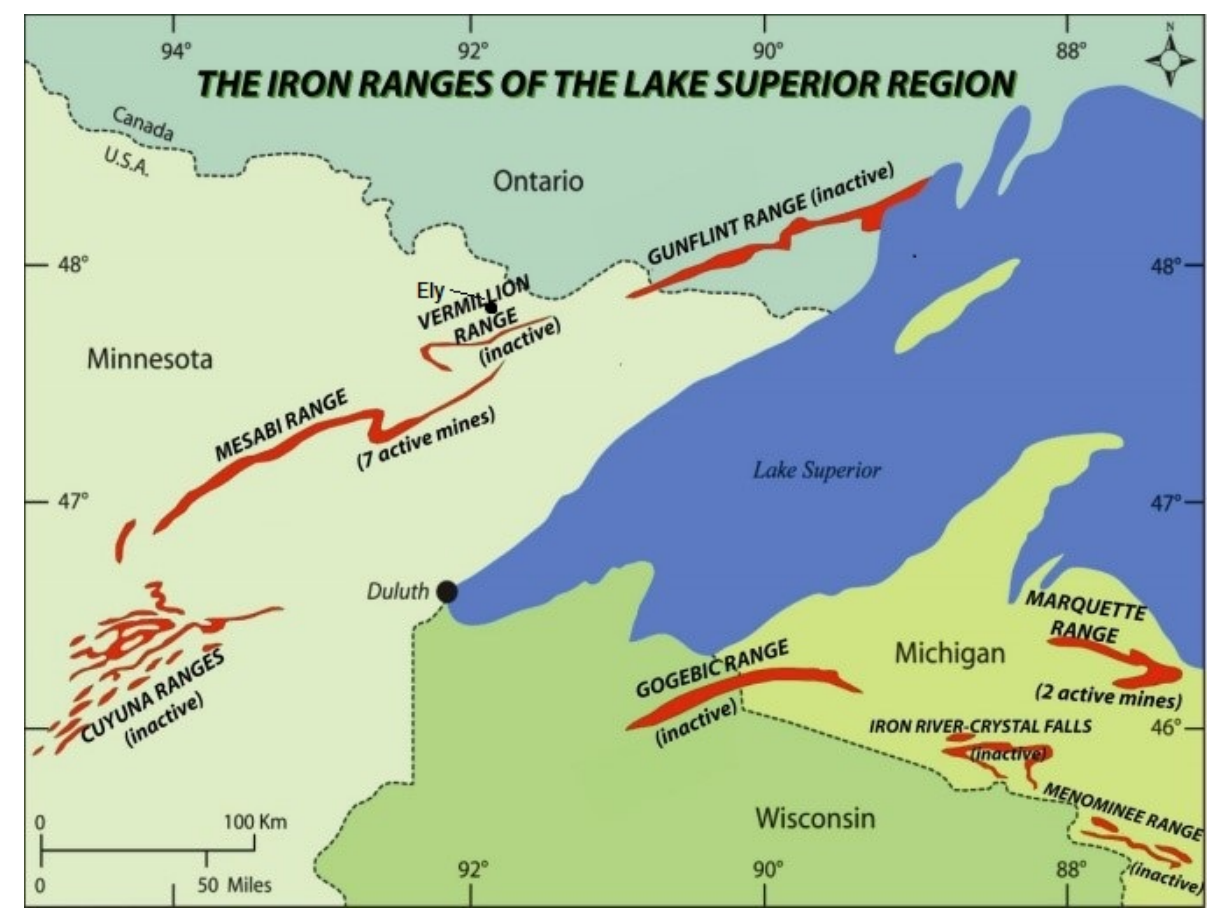

Figure 1: The Iron Range (Ely is shown). Source: Wikimedia Commons.

There are tensions between long-time residents with newer arrivals that have different class and regional backgrounds, and cultural tastes. These differences are symbolized in outdoor recreation, where longer-term working-class residents often enjoy using motorboats and ATVs to fish and hunt. The newer residents and tourists from urban and middle-class backgrounds often prefer non-motorized recreation like canoeing and hiking (Backes 1991). Newer residents have also been more active in environmental organizations that advocate for conservation.

\section{Controversy over proposed copper mining}

Since the early 2000s, mining companies have spurred a boom in exploration of nonferrous (ores that do not contain iron) metal deposits in Northeastern MN that are estimated to contain one of the world's largest reserves of copper, as well as deposits of nickel and other precious metals (Richardson 2014). The deposits that Twin Metals want to extract are nine miles southeast of Ely and in some places adjacent to the BWCAW (Bjorhus 2019; Brubeck 2016). High global prices for copper and nickel, increasing industrial demand for the metals, and slowing production in other parts of the world made the deposits attractive to the industry. However, Minnesota has no copper or other nonferrous mines and as of August 2019, the proposals remained embroiled contested decision-making and legal processes that date back at least a decade. Decisions about copper mining development are determined by a complex mix of local, state, and national government agencies. For all 
proposed mines, the Minnesota Department of Natural Resources issues the key Permit to Mine (Minnesota Department of Natural Resources 2019). Depending on who owns the land and resource rights, and what water bodies and land are impacted, other state and federal agencies are also involved.

Companies initially predicted that copper mining proposals would sail through government approval. However, the projects sparked public scrutiny and became one of the most contentious political issues in Minnesota. Copper mining has gone from being a narrow technical issue to one of broader social and political concern that is symbolic of rural-urban and class divides, and tensions between Minnesota's iconic mining industry and the state of '10,000 lakes' (M.L. Smith 2014). Government agencies received record numbers of public comments on the projects, and public hearings have attracted thousands of attendees, as well as rallies by environmental and pro-industry groups (Meersman 2010).

The copper mines present more environmental risks than the existing iron mines. Copper mines would extract small amounts of metal from ores that contains sulfides, which create hazardous sulfuric acid and can leach heavy metals when exposed to air and water (T. Myers 2016). The Twin Metals proposal is on undeveloped land near Ely and would be the first in the watershed of the BWCAW. Water pollution could flow into lakes within the BWCAW and disrupt the unique ecosystem (T. Myers 2016). Another proposal by PolyMet, whose parent is the Anglo-Swiss multinational, Glencore, is not within the BWCAW watershed but is on U.S. Forest Service Land and in the watershed of Lake Superior, and upstream of the Fond du Lac Band of Lake Superior Chippewa reservation (J. Myers 2013).

Environmental organizations and some tourism and outdoor recreation groups have raised concerns about the environmental risks, including water pollution and destruction of public lands, and mobilized to stop or delay the projects. The major mainstream environmental groups in Minnesota that are based in Saint PaulMinneapolis, the large metropolitan area and state capitol, have been involved along with some smaller and local groups such as the Friends of the BWCAW and Northeastern Minnesotans for Wilderness (NMW) based in Ely. NMW formed the Campaign to Save the Boundary Waters (CSBW) in 2013 to generate support for protecting the BWCAW from copper mining which has grown from a locally-led effort to a national campaign. The national strategy has also exacerbated perceptions among Iron Range residents that outsiders, including federal bureaucrats and upper-class elites, are trying to dictate the future of their home (Kojola 2019).

Support for copper mining has grown in response to the opposition. What was initially the public relations efforts of a few mining corporations, has expanded to broad social mobilization from construction and mining unions, Iron Range residents, community organizations, and local politicians. A new coalition - Jobs for Minnesotans - was formed in 2012 as an alliance between the Minnesota Building and Construction Trades Council, and the Minnesota Chamber of Commerce to promote copper mining as well as oil and gas pipelines (Jobs for Minnesotans 2012). Grassroots pro-mining groups have also formed that organize through social media and personal networks.

\section{Environmental imaginaries, temporality, and emotions in resource extraction conflicts}

Political ecology examines conflicts over how, when, and where development of natural resource extraction occurs, particularly how different social actors and institutions assign meaning and value to nonhuman nature (Appel et al. 2015; Huber 2013; Neumann 2005). Decisions made about development are sites of struggle between different economic, political, and ideological forces and are shaped by different meanings and knowledge about the environment that vary across race, class, and gender (Forsyth 2003; Peet and Watts 1996; Robbins 2012). While political ecology scholarship has examined questions of scale and space in natural resource politics (Andrews and McCarthy 2014; Norman, Cook and Cohen 2015; Sheppard and McMaster 2008), temporal dynamics can receive less attention. I explain how examining timescapes can advance political ecology scholarship to address how people understand nonhuman nature and industrial risks through ascribing meanings to the past, and visions for the future. I emphasize the emotional connections to collective memories and future imaginaries to demonstrate why temporalities motivate action and why they matter politically. I also contribute to literature on collective memory by demonstrating the importance of land 
and natural resources in constructing narratives about the past and explaining why collective memories are central to people's identities and emotions.

Peet and Watts' (1996) concept of environmental imaginaries describes the discursive and cultural, rather than strictly material and economic, aspects of conflicts over the construction of socio-natures and the use of nonhuman materials. Environmental imaginaries are conceptual frameworks for how people make sense of and relate to nonhuman nature. These provide ways to interpret how humans should relate to nonhuman nature and guide social practices (Gabriel 2014). Jasanoff and Kim's (2015) concept of sociotechnical imaginaries emphasizes the competing moral visions for a good society and power dynamics in decisions about implementing technology.

I build on these approaches by examining how environmental imaginaries are created through temporalities, particularly visions of the past and future that provide emotional meaning. Thus, I contribute to an emerging area in political ecology scholarship that explores temporal dynamics of relationships with nonhuman nature (Ferry and Limbert 2008; Li 2017; Szolucha 2018; Weszkalnys 2014). Temporality is important for environmental politics because notions of time shape social action and how people understand the "environment" including the risks and benefits of development (Szolucha 2018). Mathews and Barnes (2016) describe a "politics of prognosis" to account for the political processes of making predictions about environmental impacts and economic growth. These predictions are taken up by institutions and publics in ways that motivate future-oriented action. Yet, there has been little research on the social, discursive, and cultural aspects of how these predictions are made meaningful. Thus, I emphasize cultural and emotional dynamics by assessing the timescapes and collective memories that inform people's worldviews and animate emotional responses to resource extraction.

Environmental imaginaries are constructed through people's broader timescapes - the temporal social practices and cultural frameworks that organize how people see the past and future (Adam 1998; White 2017). Collective memories are central to peoples' timescapes. These are shared narratives and representations of history that are used to remember the past, make sense of the present, and construct visions of the future (Olick 2011; Olick and Robbins 1998; Kubal and Becerra 2014). Representations of the past do important political work because they shape how people interpret the present, anticipate the future, and take future-oriented actions (Abram and Weszkalnys 2013; Appadurai 2013; Bear 2014). Constructing collective memories is a struggle over who can legitimately represent the past and speak for the future (Olick and Robbins 1998; Hodgkin and Radstone 2003; Lipsitz 1990; Molden 2016). Collective memories can ingrain hegemonic ideologies into taken for granted ways of understanding the past and future. Yet, alternative memories can animate counterhegemonic visions for a more just future (Bocock 1986; Smith 2004).

The power of environmental imaginaries and timescapes is related to the emotional meanings of the past and future, particularly nostalgia and hope, and how collective memories evoke identities and connections to place. Yet, these affective dynamics are often underexamined in political ecology and STS scholarship focused on expertise and quantification of the future (Baker, Ekstrom and Bedsworth 2018; Kneas 2016; Le Billon and Sommerville 2017). Emotional memories of the past shape peoples' desires for the future, which mobilize forward-thinking action (Bonnett 2010; Campbell, Smith and Wetherell 2017; Smith and Campbell 2017), particularly actions to defend livelihoods and land (Weszkalnys 2016). Nostalgia is politically generative as it evokes longing for an idealized past and hopes for creating a prosperous future (Bonnett and Alexander 2013; Boym 2001; Davis 1979; Legg 2004). Nostalgia is not inherently reactionary or progressive, and can mobilize both conservative and progressive movements (Bonnett 2010).

A political ecology approach emphasizes the underexamined role of landscapes and experiences of nonhuman nature in how timescapes and collective memories are constructed. Dominant narratives about the past are constructed through transformations of physical space, such as built infrastructure and land use changes, and through official memorials and museums (Hodgkin and Radstone 2003; Jones and Garde-Hansen 2012; Wheeler 2014). In mining regions, like the Iron Range, the remnants of extraction, such as open pits and piles of waste rock, inscribe history onto the landscape. Mining heritage sites craft official narratives about the past that often valorize the contributions of extractive industries (Lewin 2019; Wheeler 2014, 2017) and create what Strangleman (2013) calls "smokestack nostalgia." 
Decisions made about resource and land use are often temporal struggles over the past and future. They are attempts to enact divergent environmental imaginaries. How people assess the risks and benefits of future industrial development depends on how they remember the history of industry (Messer, Shriver and Adams 2015). Perceptions of industrial development are shaped by related visions of the future - hopes for prosperity and fears about potential economic busts and environmental risks (Weszkalnys 2016). These decisions become struggles to enact different visions of a good society (Baker, Ekstrom and Bedsworth 2018; Mische 2014). In Burnham et al.'s (2017) study of conflicts over bioenergy development, they examine the "politics of imaginaries" and show how social actors promote different forms of development and technology to enact their visions for a good life.

Evoking nostalgia and creating hopeful visions of the future is important for generating popular support and legitimacy for extractive industries (Kneas 2016; Li 2014; Mathews and Barnes 2016). Depictions of an idealized past and narratives about mining 'building' the nation or local community are key for legitimizing new extractive developments (Mathews and Barnes 2016; Weszkalnys 2016). Since nostalgia is often a response to social change and upheaval (Boym 2001; Turner 1987), it resonates in extractive regions where busts in volatile extractive economies create material hardships, a sense of mourning, and a longing to renew an idealized boom era (Roberts 2008). Mining companies gain local support by creating forecasts of mineral abundance, jobs, profits, and safe mining (Kneas 2016). I argue that trust in these predictions depends not only on expertise and technical authority, but also on being interpreted as legitimate and resonating with peoples' environmental imaginaries and timescapes.

Yet, alternative environmental imaginaries and timescapes can also mobilize resistance to extractive capitalism. For example, local knowledge and memories about the ill health effects from industrial pollution can create counter-hegemonic interpretations of mining history (Adams et al. 2018; Messer, Shriver and Adams 2015). Mining proposals can create anxiety about uncertain economic benefits and environmental degradation (Weszkalnys 2016). Environmentalists who oppose extractive development are often motivated by different environmental imaginaries and collective memories (Ladino 2012). Nostalgia for nature can mobilize support for protecting land from hazardous development and legitimate environmental conservation policies (Acharya, Paudel and Upton Hatch 2009; Ladino 2004, 2012). The mainstream U.S. environmental movement traditionally focused on conservation and appealed to restoring a pre-industrial golden age linked to nostalgic myths about the frontier and the idealized simplicity of a pre-modern world and Edenic past (Cronon 1996; Slotkin 1981).

In this article, I emphasize different class and regional environmental imaginaries and timescapes mobilized by mining opponents and proponents, and how these frameworks inform perceptions of risks and benefits from proposed mines. I draw on ethnography, discourse analysis, and interviews to explore how three different sets of actors, local mine supporters, mining companies, and environmentalists, make sense of the proposed copper mines in Minnesota through divergent temporal environmental imaginaries.

\section{Analysis: competing memories and future visions in the Iron Range}

During a summer of fieldwork in the Iron Range town of Ely, MN, I observed everyday life and gained a sense of the cultural and physical landscape. I also visited memorial sites and museums that shape how the region's history is represented. In-depth interviews with residents, union leaders, local politicians and community leaders, mining industry representatives, and staff and volunteers with environmental organizations gave me deeper insight into how people understood the proposed copper mines and why they were involved in promoting or opposing them. I examine how the temporal and emotional dynamics of environmental imaginaries, particularly collective memories, shape the ways that social actors understand potential risks and benefits, and make claims to legitimacy. This helps to explain why a potentially uncontroversial technical issue about economic development in a rural mining region became so contested.

Conflict over proposed mining in Northern Minnesota is a struggle over competing memories and visions of the environment; an industrial mining landscape or a wilderness recreation landscape. The mining industry and its supporters view the region's natural resources as a source of potential value waiting to be extracted, and they will usher in a new mining future and a return to the good life. On the other hand, environmental groups 
and activists opposing the projects understand mining development as bringing pollution that also threatens their memories of outdoor recreation and visions of pristine wilderness areas and sky-blue waters. Next, I explore how these different temporal environmental imaginaries vary across social locations and how they animate conflicts over resource extraction and the "politics of prognosis" (Mathews and Barnes 2016).

\section{Supporters' hopes for renewing a nostalgic mining past}

Support for proposed copper mines among Iron Range residents, union members, and community leaders was shaped by "smokestack nostalgia" for an idealized industrial past (Strangleman 2013). This collective memory informed a hopeful vision for future prosperity created by a new type of mining.

One way in which dominant collective memories are created is through official and semi-official narratives about the past, which have important political and ideological effects (Hodgkin and Radstone 2003). I find that institutionalized narratives about the Iron Range's history in cultural institutions, like museums and memorial sites, construct nostalgic collective memories about the legacy of mining. This reinforces the sense that the mining industry is essential to the community while also silencing problems and critical memories. On a rainy Sunday afternoon in the summer of 2017, I went to the Soudan Underground Mine State Park which is a former iron mine converted into a park run by the Minnesota Department of Natural Resources. The mine operated from 1882 to 1962 and was the largest underground mine in Minnesota. I went to the visitor's center, located in an old mine building, to take a tour into the old mine shaft. Before the tour, we were shown a short video about the history of the mine. The film opens in the 1950s describing Soudan as "the Cadillac of underground mines" because it was the biggest and state-of-the-art. The narration frames the broader 1950s as a time of prosperity for Americans with a good economy and President Dwight "Ike" Eisenhower leading the country. There is footage of iconic images from the 1950s such as new cars being driven off the lot of car dealerships, bustling suburban shopping malls, and an Elvis concert. The film then cuts to interviews with former miners who described their pride in producing large amounts of iron-ore and how they formed a close family with their fellow miners. The film focused on the supposed heyday of mining, rather than violent labor struggles in the early 20th century or the downturn in mining during the 1960s that led to closing the facility.

Collective memories of iron mining and the region's history are dominated by these nostalgic narratives about the mining heyday and the good life. In my conversations with Iron Range residents and local leaders, they regularly brought up emotional connections to collective memories of the region's prosperous past. Mining jobs were said to support stable middle-class families with good union wages that created a sense of social cohesion and provided people with time-off and resources to enjoy the outdoors. I often heard stories about miners leaving a shift in the summer and immediately getting in their trucks and driving to the nearby lake to go fishing. For example, a middle-aged white male who grew up on the Iron Range, but didn't work in the iron mines, reflected on memories of a time with more economic opportunity when men could easily get a mining job without a college education:

A lot of the guys went right from high school, went right to the mines to work. It was that simple. You knew that when you graduated from high school that if you wanted a job, all you had to do was go into the human resources office at Reserve Mining or Minntac [iron mines] or wherever and go, "I'm going to go to work."' They'll say, "All right. We're going to put you on a production truck. Here you go."

Mining was presented as essential to the region's history and lifestyles. An Iron Range state legislator expressed this centrality of mining when he told me that people were used to mining since it was part of their way of life:

People up here [the Iron Range] understand it a little bit more just because we've been in the hotbed of mining for 135 years, and it's something we grew up with and understand very well, just like a farmer understands farming and factory working areas understand manufacturing. 
The banality of mining and its long history creates a sense of familiarity with the industry and in turn, a trust that new companies will use technology to best protect the environment.

Collective memories of hard work by men in the mines was emotionally resonant with peoples' gender identities and their notions of masculinity, which has contributed to a desire for new copper mines. A working class Iron Ranger was tied to doing physical and masculine labor that provided for one's family. Thus, memories of a mining heyday can reproduce an idealized gender division of labor and the image of heroic male workers (Lewin 2019; Scott 2010). For example, a retired teacher reflected on his childhood when men worked in Ely's iron mine while women stayed home:

He [my dad] was at the Pioneer Mine and of course my mother, she didn't work...My dad, he was a hard worker. He basically worked in the mine and then on weekends he would go out and cut pulp wood. That's a time when everything was done by hand of course with your crosscut saws. He told me he was getting about five cents a stick at that time. He was a worker, I'll tell you. I don't know how he did it, but he kept going.

Nostalgia shapes how physically demanding work is remembered as a form of valiant masculine labor during simpler times when people could make ends meet. Meanwhile, the occupational hazards and the toll on peoples' bodies are silenced.

Nostalgia includes less references to past struggles and injustices, while creating optimism for renewing the past (Boym 2001; Legg 2004). Overlooked in the popular collective memory of the Iron Range are histories of corporate exploitation and oppressive gender relations. Workers engaged in intensive organizing and endured brutal and violent repression from mining companies in the early to mid-20th Century to form unions and demand better pay and working conditions (Manuel 2015). Employment in the iron mines also was, and is, dominated by men. Getting jobs for women in the iron mines required federal lawsuits in the 1970s to force the companies to hire women. Then, when women entered the workplace, they faced rampant sexual harassment, culminating in the Jenson v. Eveleth Taconite Co. court case in 1997, the first class-action sexual harassment lawsuit in the United States (Bingham and Gansler 2003). Yet, many women are active in supporting the new copper projects, which points to the ways that mining is intertwined with the identity and history of the Iron Range, beyond individual negative experiences in the gendered labor market.

As Hodgkin and Radstone (2003) argue, the ability to construct the past is politically powerful because how the past is remembered is key to how the future is imagined. When mining is remembered nostalgically as building the community, then more mining is seen as inevitable and the only way to breathe life back into dying mining towns. New copper mining companies framed themselves as continuing this history and they connected predictions of future growth to nostalgic memories. For example, the PolyMet website says that they, "...will continue the proud mining tradition on the Iron Range. Mining in Minnesota's Iron Range has sustained tens of thousands of families, dozens of communities, schools, commerce and recreation centers" (PolyMet 2016).

The proposed copper mines provide a sense of hope in response to loss and decline, which is common in boom and bust resource economies (Freudenburg 1992). This contributes to a desire among residents to trust company models projecting job creation and economic growth. A retired miner and community leader in a small Iron Range town reflected on economic struggles and the boost new mining could provide:

It [copper mining] would be a big benefit for the Range. It would help our economy come back. It would help our small town. We're losing a lot of stores that are closing and stuff around here is having a tough time making it.

Hopes for the future among pro-mining residents were not simply about the material benefits from renewed extraction, but also about revitalizing a sense of community identity, history, and pride tied to labor, class, and masculinity. People expressed an emotional desire to restore a time when downtown main streets 
were full of businesses and the houses were full of young families whose kids filled the local schools. I met a retired miner who lived with his wife in a small town that was built by a now defunct iron mining company. The iron mine has closed, but PolyMet is now proposing to repurpose the old facilities - the future of mining could emerge from the ruins of the past. In our interview he reflected on his hopes for copper mining to renew a sense of vibrancy to the community and attract young people:

It would generate more of an upbeat atmosphere of course and there'd be new people coming in that wanted maybe a different business in town. There'd be more money flow for sure. We're basically now...we are either on welfare or retired.

Yet, the hopeful projections of copper mining bringing prosperity do not address many of the underlying factors causing higher unemployment and a lack of good jobs. For example, much of the job loss in the iron mining industry is due to automation (Manuel 2015), and copper mines would likely be highly automated and mechanized. New mines will require high-skilled and technical labor, thus companies may bring in outside workers rather than hire locally. The proposed mines will also have a limited lifespan - some of the initial permit applications are for 20 years of operation.

\section{Opponents' memories and visions of wilderness recreation}

Environmental organizations and activist's opposition to the copper mines was motivated by different temporal environmental imaginaries, tied in particular to memories of outdoor recreation. In their perspective, shaped by different class positions and places of residence, the land should be preserved for conservation and wilderness protection. This can create the good life of outdoor recreation and tourism, and a future that protects ecological and public health.

The desire to protect a place that is culturally and emotionally important motivated opposition to the copper mines. Powerful nostalgic memories connected to childhood and family experiences informed respondents' hopes for the future. I regularly heard staff and volunteers at environmental organizations describe their love for the area while recounting their first experiences canoeing and camping in the BWCAW. For example, a middle-aged white male and small business owner in Ely, who is active with local and state-wide environmental organizations, reflected on idyllic memories of childhood experiences to account for his activism:

It was magical from the get go [summer youth trip to the BWCAW]. The whole thing from start to finish was absolutely life changing. I remember it like it was yesterday. I still draw on it daily, memories of sunset evenings on an island in Basswood Lake playing kick the can with my pioneer boy buddies and watching bear cubs camp around the far shore and listening to the loons and the sizzling of walleye filets on the frying pan over the campfire...That riveting experience led me to set my sights on somehow, some way calling this home someday.

His experiences are also told through cultural tropes about loons, which are an iconic waterfowl unique to the upper Midwest and identified with Minnesota, and eating walleye, which is a popular fish in the region that is often served at restaurant and fish fry events in Northern Minnesota. This illustrates the collective aspects of these memories that are interpreted through cultural frameworks, as well as the importance of nonhuman nature in peoples' memories.

Emotional connections to idyllic memories can motivate a sense of moral obligation to defend a place against potential threats. Environmentalists often described getting involved in opposition to copper mining because they wanted to protect a cherished place remembered through experiences as a child at summer camp or on family canoe trips. A middle-age woman who recently moved to Ely reflected on how mining pollution threatened her nostalgic memories of youth outdoor recreation and motivated her to speak out against copper mining: 
I was going to live in this wilderness edge community, where I was going to be able to do something that I loved that had been a part of my life since I was a teenager, and the idea that that was threatened was scary or an affront, or certainly something that I should not just roll over and play dead.

Environmental organizations used these culturally and emotionally important memories strategically to frame copper mining as a threat and in order to mobilize supporters. A middle-aged white man active with local environmental organizations described how they recruit supporters and sway public opinion through appeals to preserving people's emotional memories of the landscape:

Hundreds of thousands of people have been here over the years and they don't forget it. This place influences more people emotionally. When you get an emotional tie to a place you've got a real strong hold on those people.

Yet, the environmental imaginary of mining opponents is also selective and a politically-motivated representation of the past. Descriptions of a pristine wilderness reflect how wilderness as a place untouched by humans is a socially constructed notion, and a romanticized vision of the past (Cronon 1996). The area is evidently not devoid of human and industrial impacts. Parts of the BWCAW had active logging into the early $20^{\text {th }}$ century. There were also cabins and resorts that were accessed with motorboats and small airplanes until Federal wilderness protections in the 1960s banned motors and removed private properties (Proescholdt, Rapson and Heinselman 1995). Ojibwe and other Indigenous peoples have also used the region for thousands of years for hunting, fishing, and gathering, and as a trading and transportation route (Backes 1991).

Environmentalists also understood the mining past differently than mine supporters as a result of their class position and place of residence. Opponents were often from more urban parts of the state and country, and were middle-class professionals with college educations, for example schoolteachers. Class differences are largely related to different cultural habitus and education, rather than wealth differences. Unionized mine and construction workers likely have similar, if not higher, salaries than teachers and people working in tourism. Opponents of copper mining did not share the collective memories and class-based identities of long-time Iron Range residents. Instead, they remembered a legacy of environmental pollution, land degradation, and economic instability. They thought more mining would bring the same.

A more pessimistic understanding of the legacies of iron mining led opponents to think a new alternative vision for the place was needed. Thus, they constructed visions of a more prosperous future based on outdoor amenities in which people move to the area for jobs in tourism, light manufacturing, and teleworking. This path could revitalize the local economy and social life. A staff member of a state-wide environmental organization remarked that mine supporters were stuck in the past and that Iron Range towns needed a different future:

I think that there's more of people looking in the rearview mirror. Like, mining is the only thing we need, and we just got to do that. There's the other group, which is like, no, we can do other stuff. Trying to figure out a different future for the town.

The critique of pro-mining timescapes reflects environmentalists' class position of working, or being retired from, white-collar jobs or jobs in the tourism and service industry. They did not have material interests tied to mining or nostalgic memories of the industry. Instead, their timescape is shaped by outdoor recreation and environmental conservation.

\section{Contested assessments of uncertain futures}

Divergent timescapes and environmental imaginaries lead mining supporters and critics to have different assessments of the potential risks and benefits from copper mining. This demonstrates how collective memories 
and imaginaries are important in how people perceive extractive development (Messer, Shriver and Adams 2015; Roberts 2008) and the emotional and cultural aspects of the "politics of prognosis" (Mathews and Barnes 2016). A staff member of a state-wide environmental organization in his late thirties reflected on these divergent visions and perceptions of future risk:

I think everybody wants the best, you know I don't think anyone has ill intentions. Everyone just has a different idea of what they think is going to be best for our community and for the region. I think there is just disagreement over what we want the future to look like. And also, how likely it is that there would be significant pollution or negative effects from the mine.

People's trust or skepticism in government and corporate forecasts about environmental contamination and job creation depends on whether they view iron mining as having a clean or polluting history. How industrial history is remembered impacts on how the future is envisioned (Burnham et al. 2017; Messer, Shriver and Adams 2015). For many long-time Iron Range residents, iron mining is remembered as having a clean and safe history and therefore, copper mining would also be clean. An editorial in the Ely Echo (2017), a popular community newspaper in Ely, argued that the Twin Metals project should go forward since iron mining had not polluted the area and local residents would not let their home be destroyed:

we'd [locals] like to be able live, work and recreate here just as we have for over 130 years. Natural resource extraction has been going on here the whole time and yet by some miracle you can drink the water and eat the fish. Even out of a mine pit. Imagine that.

Working class and rural residents resented being portrayed as not caring about the environment and asserted experiential knowledge and collective memories of using the land to claim they cared more about protecting the place than outside environmentalists. People often recounted memories of spending their spare time hunting, fishing, and riding snowmobiles and ATVs; activities that coexisted with iron mining. A mayor of a small Iron Range town described how she felt that locals had cared for the environment and that outside environmentalists should focus on urban pollution where they lived:

I am definitely concerned about the environment. I get that. They [environmentalists] seem to think we don't get that. But our water is cleaner than where they live in Minnetonka [wealthy suburb of Minneapolis]. So, I think we're doing something right.

However, comparisons to the history of iron mining overlooks the additional hazards from copper mining and shows how optimistic "smokestack nostalgia" can lead people to downplay potential hazards. Nonferrous mines, including copper, have often become Superfund sites, a U.S. government program to cleanup industrial contamination and hazardous waste (Earthworks 2017; U.S. EPA 2015). Some of the proposed copper mines are also located in more environmentally-sensitive and culturally important areas than the existing iron mines, particularly the largely unpolluted and ecologically sensitive BWCAW.

The greater risks from copper mining do challenge local support and create some uncertainties among residents and workers. Support for hazardous industries can be challenged when development creates anxieties about pollution (Weszkalnys 2014). However, people reconciled these risks with trust in supposedly rigorous environmental regulations and their experiential history with the industry. A retired miner in Ely told me that while he supports copper mining exploration, he does not ignore the risks since he has experience with the industry. He thinks companies should get permits only if they follow all environmental regulations and prove it can be done safely: 
I don't want to be blind here. Growing up here [Ely] I know what we have, and I don't want anything to happen, like polluting the area...This mining stuff, yeah, there's pros and cons. There's always going to be pollution, I don't care how careful you are. I don't want to see anything happen to us, to anybody.

On the other hand, environmentalists questioned water pollution models about safe emissions levels, partially because they did not trust the companies or regulators given a history of pollution. A woman who worked for an environmental organization and lived in a Northern Minnesota city questioned company claims about safety by reflecting on the long time horizon of pollution, while connecting the future risks of mining to its dirty history:

I think that the number one thing is that the pollution from them [copper mines] lasts so long, so many years, hundreds, thousands of years into the future. There are still mines from the Roman Empire that are polluting water in Europe. At PolyMet, while they're going to have a water treatment plant that is going to treat the polluted discharge from the mine pits, we have no idea what's going to happen in the future as far as our social and economic and regulatory systems. The idea that what we've got now is going to continue for a thousand years with no breaks... The experience in the past is that mining companies always under-predict what the impacts on water quality are going to be.

Perceptions of risk also depend on concerns about the future, either the fear of depressed mining towns or the fear of environmental destruction from industrial development. Both sides then assert moral claims about fighting for future generations and leaving a better world behind. Yet, their imaginations for the future and priorities of what should be preserved are different. This shows the different moral visions that are part of sociotechnical imaginaries and environmental politics (Jasanoff and Kim 2015).

For supporters, mining would bring economic prosperity that could keep rural mining communities alive by creating jobs for future generations. They see an ethical obligation to promote mining so their children and grandchildren can continue to live in the region and achieve the good life. A retired male schoolteacher in Ely who supported copper mining reflected on the region's future being intertwined with mining:

I really think the only future that the Iron Range has is going to be in mining without a doubt.

That has been our lives, been our life throughout. I think it's going to be in the future.

Mining development is understood as the only way for the region to have a future because mining defines its past, present, and future. Preserving the outdoors for future generations and passing on traditions of hunting, fishing, and boating also depends on people being able to find decent jobs so they can stay in the area and afford to spend time outdoors. The desire to provide for the next generation contributes to individuals downplaying risks, and expressing trust in corporate forecasts of safety and job creation.

On the other hand, mining opponents saw the projects as opposed to their future environmental imaginary and vision of the good life. Environmental groups made emotional and moral appeals to protect the area for use by future generations. A volunteer with an environmental organization who was in his mid-fifties described an obligation to be stewards of the wilderness and pass it on for their children to create the same memories, "The important thing is to keep it as a wilderness for you and your children and my grandchildren."

Opponents emphasized the potential long time horizon of pollution from mining. They described how mining wastewater needs to be stored in perpetuity, since the potential for mining spoil to generate acids and heavy metals endures for hundreds of years. In order to highlight the long-term risks of pollution, environmental groups talked of a five hundred year time horizon, a figure actually taken from company pollution modeling done for an environmental impact assessment. 'Five hundred years' came to symbolize ongoing risks that extend 
beyond the life of any single company and, therefore, their ability to ensure accountability. A middle-aged white environmental activist talked about the symbolic power of '500 years' to represent a tangible threat:

When you look at the PolyMet EIS, they talk about 500 years of treatment. 500 years, no big deal. We as humans have a hard time understanding geologic time, we can't even understand 500 years, that goes right over everybody's heads. 500 years...this [the U.S.] has been a republic for what 250 years or something?

Memories of the past and hopes for the future inform how people assess claims about potential risks and benefits from extractive development. Thus, trust in corporate and government predictions is not simply determined by expertise, but also how predictions align with peoples' timescapes and environmental imaginaries. Different class and place-based timescapes shape imaginaries of the good life, while moral claims about protecting the future drive conflicts over technology and development (Jasanoff and Kim 2015).

\section{Conclusion}

Through a case study of contested copper mining development in the Northern Minnesota Iron Range, I have demonstrated how the temporal and affective aspects of environmental imaginaries animate conflicts over natural resource use. Support from working class and rural residents and opposition from environmentalists to proposed mining is driven by nostalgia, fears of loss, and hopes to protect places and the region for future generations. Yet, how people remember the past and imagine future impacts of mining are radically different, based on divergent environmental imaginaries shaped by class, and by place of residence. Supporters see a return to a prosperous mining heyday while opponents see devastation of a pristine recreation landscape. Nostalgic memories leave out awkward historical events on both sides, including pollution from iron mining and exploitative labor relations, and the previous use of wilderness areas by industry as well as by Indigenous people.

Many long-time Iron Range residents support copper mining development and trust company and state projections of job creation and safe pollution levels. This aligns with an environmental imaginary that is constructed through class and place-based collective memories of hard work in the older iron mines, bringing prosperity and leaving behind a clean environment. This reflects how resource extraction is often imbued with social meaning through nostalgia, and with hopes for a return to the 'good life.' This narrative is culturally and politically powerful in mining regions where extractive capitalism has generated idyllic memories of boom times and anxieties about busts (Frickel and Freudenburg 1996; Lewin 2019; Wheeler 2014).

Extractive industries, however, encounter friction when they pursue new development in places that have competing environmental imaginaries and timescapes linked to outdoor recreation and conservation. For environmental opponents of mining, new copper mining proposals present a rupture to their collective memories of outdoor recreation and family vacations. This is an unacceptable risk to their visions of a prosperous future based on environmental conservation and tourism. Thus, they do not trust corporations' and state agencies' predictions of safety. Many staff and supporters of environmental organizations are from urban areas outside of the Iron Range, or relocated to the area, and are largely middle-class professionals who do not share working class Iron Range residents' collective memories of mining.

Despite the increased public concern and delays to development, the environmental imaginary of the mining industry and its supporters appears to be succeeding in part. As of spring 2019, the PolyMet project had acquired most of the necessary permits, although in 2020 there are remaining lawsuits and potential political interventions that are still blocking construction. The future of other projects, especially Twin Metals which is adjacent to BWCAW federal wilderness area, has fluctuated over time. In 2017, the project appeared to be moribund as the Obama administration cancelled the company's mineral leases and initiated a 20-year moratorium on mining in the area to study environmental impacts. However, the Trump administration reversed these actions and by spring 2019 Twin Metals was moving forward with planning and exploration. 


\section{Contributions and implications}

This article advances political ecology research on natural resources by developing the temporal and emotional dynamics of environmental imaginaries through theories of timescapes and collective memories. First, I argue that relationships to the nonhuman environment are understood and contested through emotional meanings of the past and future, demonstrating Weszkalnys' (2016) claim that resource extraction is a politicaleconomic and affective process embedded in different temporalities. How people remember the environmental and economic history of an industry and a place informs how they assess risks and benefits of future development (Messer, Shriver and Adams 2015).

Second, I argue that nostalgia and other emotional components of environmental imaginaries are not inherently reactionary or progressive but can be taken up by different political projects. This advances scholarship on nostalgia as productive, rather than simply reactionary, by demonstrating the role of nonhuman nature and collective memories of the environment (Blunt 2003; Bonnett and Alexander 2013; Wheeler 2017). I argue that collective memories are politically powerful because of their affective meanings that mobilize social action and constrain visions for future possibilities (Blunt 2003; Bonnett 2010; 2016; Smith and Campbell 2017). The ability of industries and corporations to construct a locally dominant collective memory valorizing the legacies of industry, a form of "smokestack nostalgia" (Strangleman 2013), strengthens local support for development and silences past problems. This creates a sense of capitalist extraction being inevitable, which constrains imagining and enacting alternative futures. But the hegemony of extractive industries can also be challenged by competing environmental imaginaries, based particularly on emotional connections to memories of recreation, and fears about long-term pollution risks to a culturally important place.

Thirdly, there is potential for alternatives and collaboration in disrupting the hegemony of extractivism, but these efforts must overcome divergent environmental imaginaries and timescapes that are deeply entrenched across lines of class and regional identification. Nonetheless, there are shared identities between the two camps. In Iron Range communities, there are collective memories of mine worker resistance and organizing, and occupational hazards that could disrupt the nostalgia for mining and the hopeful promises made by new corporations. Many Iron Range residents are also active outdoorspeople and express concerns about environmental protection. Thus, environmental imaginaries linked to critiques of corporate power and protecting forests and lakes for public use could align local residents and local or regional environmentalists. A shared discourse needs to overcome rural-urban and class differences in political culture while addressing the material realities of peripheral extractive regions. Mainstream environmental organizations opposing copper mining could go much further in their recognition of environmental injustices and economic issues. They have struggled to craft a vision for alternative economies that resonates with blue-collar workers and rural residents.

While I emphasize the cultural and discursive aspects of environmental imaginaries and timescapes, this does not negate political, material, and economic dynamics. When and why companies invest in new mining projects is shaped by global markets and prices, and by projections of future profits. Local support for a hazardous industry is shaped by socio-economic conditions, particularly the boom and bust cycles of extractive industries. Delaying development is also a political strategy for its opponents, as drawn-out regulatory processes and litigation increase corporate costs, altering corporate decisions as commodity prices fluctuate. Future scholarship on resource extraction should connect research on political-economic and discursive dynamics of temporality to provide new theoretical insights and political analysis.

\section{References}

Abram, S. and G. Weszkalnys. 2013. Elusive promises: planning in the contemporary world. New York: Berghahn.

Acharya, R.N., K.P. Paudel and L.U. Hatch. 2009. Impact of nostalgia and past experience on recreational demand for wilderness. Applied Economics Letters 16(5): 449-453.

Adam, B. 1998. Timescapes of modernity: the environment and invisible hazards. London: Routledge.

Adams, A.E., T.E. Shriver, A. Saville and G. Webb. 2018. Forty years on the fenceline: community, memory, and chronic contamination. Environmental Sociology 4(2): 210-220. 
Andrews, E. and J. McCarthy. 2014. Scale, shale, and the state: political ecologies and legal geographies of shale gas development in Pennsylvania. Journal of Environmental Studies and Sciences 4(1): 7-16.

Appadurai, A. 2013. The future as cultural fact: essays on the global condition. London: Verso.

Appel, H., A. Mason, M.J. Watts and M.T. Huber (eds.). 2015. Subterranean estates: life worlds of oil and gas. Ithaca: Cornell University Press.

Backes, D. 1991. Canoe country: an embattled wilderness. Minocqua: NorthWord Press.

Baker, Z., J. Ekstrom and L. Bedsworth. 2018. Climate information? Embedding climate futures within temporalities of California water management. Environmental Sociology 4(4): 419-433.

Bear, L. 2014. Doubt, conflict, mediation: the anthropology of modern time. Journal of the Royal Anthropological Institute 20(S1): 3-30.

Bingham, C. and L.L. Gansler. 2003. Class action: the landmark case that changed sexual harassment law. New York: Anchor Books.

Bjorhus, J. 2019. Twin Metals wins renewal of federal mining leases in northeastern Minnesota. Star Tribune, May 15.

Blunt, A. 2003. Collective memory and productive nostalgia: Anglo-Indian homemaking at McCluskieganj. Environment and Planning D: Society and Space 21(6): 717-738.

Bocock, R. 1986. Hegemony. New York: Tavistock.

Bonnett, A. 2010. Left in the past: radicalism and the politics of nostalgia. New York: Continuum.

Bonnett, A. 2016. The geography of nostalgia: global and local perspectives on modernity and loss. London: Routledge.

Bonnett, A. and C. Alexander. 2013. Mobile nostalgias: connecting visions of the urban past, present and future amongst ex-residents. Transactions of the Institute of British Geographers 38(3): 391-402.

Boym, S. 2001. The future of nostalgia. New York: Basic Books.

Brubeck, K. 2016. Obama administration takes steps to protect watershed of the Boundary Waters Canoe Area Wilderness. U.S. Department of the Interior. December 15. https://www.doi.gov/pressreleases/obamaadministration-takes-steps-protect-watershed-boundary-waters-canoe-area

Burnham, M., W. Eaton, T. Selfa, C. Hinrichs and A. Feldpausch-Parker. 2017. The politics of imaginaries and bioenergy sub-niches in the emerging northeast U.S. bioenergy economy. Geoforum 82: 66-76.

Campbell, G., L. Smith and M. Wetherell. 2017. Nostalgia and heritage: potentials, mobilisations and effects. International Journal of Heritage Studies 23(7): 609-611.

Cronon, W. 1996. The trouble with wilderness: or, getting back to the wrong nature. Environmental History 1(1): 7-28.

Davis, F. 1979. Yearning for yesterday: a sociology of nostalgia. New York: Free Press.

Donovan, A.R. and C. Oppenheimer. 2015. Modelling risk and risking models: the diffusive boundary between science and policy in volcanic risk management. Geoforum 58: 153-165.

Earthworks. 2017. Financial Assurance and Superfund: who should pay for mine clean-up, industry or taxpayers? [Accessed June 6 2018]. https://earthworks.org/issues/financial assurance bonding and cercla 108b/

Ely Echo. 2017. What now? Editorial. June 30.

Ferry, E.E. and M.E. Limbert. 2008. Timely assets: the politics of resources and their temporalities. Santa Fe: School for Advanced Research Press.

Forgrave, R. 2017. In northern Minnesota, two economies square off: mining vs. wilderness. New York Times. October 12.

Forsyth, T.J. 2003. Critical political ecology: the politics of environmental science. London: Routledge.

Freudenburg, W.R. 1992. Addictive economies: extractive industries and vulnerable localities in a changing world economy. Rural Sociology 57(3): 305-332. 
Frickel, S. and W.R. Freudenburg. 1996. Mining the past: historical context and the changing implications of natural resource extraction. Social Problems 43(4): 444-466.

Gabriel, N. 2014. Urban political ecology: environmental imaginary, governance, and the non-human. Geography Compass 8(1): 38-48.

Goldman, M., P. Nadasdy and M. Turner (eds.). 2011. Knowing nature: conversations at the intersection of political ecology and science studies. Chicago: University of Chicago Press.

Hemphill, S. 2005. Explaining the Iron Range character. Minnesota Public Radio. September 19. http://news.minnesota.publicradio.org/features/2005/09/19 hemphills mayasichsidebar

High, S. and D.W. Lewis. 2007. Corporate wasteland: the landscape and memory of deindustrialization. Ithaca: Cornell University Press.

Hillman, M. 2007. Forty years ago, the Pioneer Mine shut down. The Timberjay. March 24.

Hodgkin, K. and S. Radstone. 2003. Contested pasts: the politics of memory. London: Routledge.

Horowitz, L.S. 2010. 'Twenty years is yesterday': science, multinational mining, and the political ecology of trust in New Caledonia. Geoforum 41(4): 617-626.

Huber, M.T. 2013. Lifeblood: oil, freedom, and the forces of capital. Minneapolis: University of Minnesota Press.

Jasanoff, S. and S.-H. Kim. 2015. Dreamscapes of modernity: sociotechnical imaginaries and the fabrication of power. Chicago: University of Chicago Press.

Jones, O. and J. Garde-Hansen. 2012. Geography and memory: explorations in identity, place and becoming. New York: Palgrave Macmillan.

Kinchy, A.J. 2012. Seeds, science, and struggle: the global politics of transgenic crops. Cambridge: MIT Press.

Kneas, D. 2016. Subsoil abundance and surface absence: a junior mining company and its performance of prognosis in northwestern Ecuador. Journal of the Royal Anthropological Institute 22: 67-86.

Kojola, E. 2019. Bringing back the mines and a way of life: populism and the politics of extraction. Annals of the American Association of Geographers 109(2): 371-381.

Kraker, D. 2016. Mine layoffs bring new calls to remake Iron Range economy, but into what? MPR News. April 11.

Kubal, T. and R. Becerra. 2014. Social movements and collective memory. Sociology Compass 8(6): 865-875.

Ladino, J.K. 2004. Longing for wonderland: nostalgia for nature in post-frontier America. Iowa Journal of Cultural Studies 5(1): 88-109.

Ladino, J.K. 2012. Reclaiming nostalgia: longing for nature in American literature. Charlottesville: University of Virginia Press.

Lamppa, M.G. 2004. Minnesota's iron country: rich ore, rich lives. Duluth: Lake Superior Port Cities Inc.

Lavanger, J. 2018. Boundary Waters Canoe Area Wilderness. MNopedia. Minnesota Historical Society. January 21. [Accessed April 20 2018]. http://www.mnopedia.org/place/boundary-waters-canoe-area-wildernessbwcaw

Le Billon, P. and M. Sommerville. 2017. Landing capital and assembling 'investable land' in the extractive and agricultural sectors. Geoforum 82: 212-224.

Legg, S. 2004. Memory and nostalgia. Cultural Geographies 11(1): 99-107.

Lewin, P.G. 2019. 'Coal is not just a job, it's a way of life': the cultural politics of coal production in central Appalachia. Social Problems 66(1): 51-68.

Li, T.M. 2014. Land's end: capitalist relations on an indigenous frontier. Durham: Duke University Press.

Li, T.M. 2014. What is land? Assembling a resource for global investment. Transactions of the Institute of British Geographers 39(4): 589-602.

Li, T.M. 2017. Rendering land investible: five notes on time. Geoforum 82: 276-278.

Lipsitz, G. 1990. Time passages: collective memory and American popular culture. Minneapolis: University of Minnesota Press. 
Manuel, J.T. 2015. Taconite dreams: the struggle to sustain mining on Minnesota's Iron Range, 1915-2000. Minneapolis: University of Minnesota Press.

Mathews, A.S. and J. Barnes. 2016. Prognosis: visions of environmental futures. Journal of the Royal Anthropological Institute 22: 9-26.

Meersman, T. 2010. Proposed copper-nickel mine draws 'extraordinary' interest. Star Tribune. February 5.

Messer, C.M., T.E. Shriver and A.E. Adams. 2015. Collective identity and memory: a comparative analysis of community response to environmental hazards. Rural Sociology 80(3): 314-339.

Minnesota Department of Natural Resources. 2019. Nonferrous metallic minerals development process. https://www.dnr.state.mn.us/lands_minerals/metallic_nf/development.html

Mische, A. 2014. Measuring futures in action: projective grammars in the Rio +20 debates. Theory and Society 43(3-4): 437-464.

Molden, B. 2016. Resistant pasts versus mnemonic hegemony: on the power relations of collective memory. Memory Studies 9(2): 125-142.

Mukta, P. and D. Hardiman. 2000. The political ecology of nostalgia. Capitalism, Nature, Socialism 11(1): 113133.

Myers, J. 2013. PolyMet review goes public. Duluth News-Tribune. December 7.

Myers, T. 2016. Acid mine drainage risks: a modeling approach to siting mine facilities in northern Minnesota USA. Journal of Hydrology 533: 277-290.

Nesbitt, J.T. and D. Weiner. 2001. Conflicting environmental imaginaries and the politics of nature in central Appalachia. Geoforum 32(3): 333-349.

Neumann, R.P. 2005. Making political ecology. Oxford: Oxford University Press.

Norgaard, K.M. 2011. Living in denial: climate change, emotions, and everyday life. Cambridge: MIT Press.

Norman, E.S., C. Cook and A. Cohen. 2015. Negotiating water governance: why the politics of scale matter. Farnham: Ashgate.

Olick, J.K. and J. Robbins. 1998. Social memory studies: from 'collective memory' to the historical sociology of mnemonic practices. Annual Review of Sociology 24(1): 105-140.

Olick, J.K. 2011. The collective memory reader. Oxford: Oxford University Press.

Peet, R. and M.J. Watts (eds.). 1996. Liberation ecologies: environment, development, social movements. London: Routledge.

PolyMet. 2016. Five reasons PolyMet mining is good for Minnesota. Go PolyMet. June 10. [Accessed May 30 2019] http://gopolymet.com/news/5-reasons-polymet-mining-is-good-for-minnesota-2/

Proescholdt, K., R. Rapson and M.L. Heinselman. 1995. Troubled waters: the fight for the Boundary Waters Canoe Area Wilderness. St. Cloud: North Star Press of St. Cloud.

Radstone, S. and K. Hodgkin. 2003. Regimes of memory. London: Routledge.

Raynes, D.K.T., T.L. Mix, A. Spotts and A. Ross. 2016. An emotional landscape of place-based activism: exploring the dynamics of place and emotion in antifracking actions. Humanity and Society 40(4): 401423.

Richardson, R. 2014. Getting the details behind copper-nickel mining in Minnesota. The Brainerd Dispatch. January 30.

Robbins, P. 2012. Political ecology: a critical introduction. Oxford: Wiley-Blackwell.

Roberts, I. 2008. Collective representations, divided memory and patterns of paradox: mining and shipbuilding. Sociological Research Online 12(6): 1-19.

Scott, R.R. 2010. Coal heritage/coal history: progress, tourism, and mountaintop removal. In Gray, H. and M. Gomez-Barris (eds.). Toward a sociology of the trace. Minneapolis: University of Minnesota Press. Pp. 137-166.

Scott, R.R. 2013. Environmental affects: NASCAR, place and white American cultural citizenship. Social Identities 19(1): 13-31. 
Sheppard, E. and R.B. McMaster. 2008. Scale and geographic inquiry: nature, society, and method. Oxford: Wiley-Blackwell.

Slotkin, R. 1981. Nostalgia and progress: Theodore Roosevelt's myth of the frontier. American Quarterly 33(5): 608-637.

Smith, A.L. 2004. Heteroglossia, 'common sense,' and social memory. American Ethnologist 21(2): 251-269.

Smith, L. and G. Campbell. 2017. 'Nostalgia for the future': memory, nostalgia and the politics of class. International Journal of Heritage Studies 23(7): 612-627.

Smith, M.L. 2014. PolyMet mine debate has competing visions for up North. Star Tribune. February 8.

Spiegel, S.J. 2017. EIAs, power and political ecology: situating resource struggles and the techno-politics of small-scale mining. Geoforum 87: 95-107.

Stock, J.H. and J. Bradt. 2018. U.S. Forest Service (USFS) environmental assessment (EA) on proposed 20year mineral leasing withdrawal in Superior National Forest. U.S. Forest Service, U.S. Department of Agriculture.

Strangleman, T. 2013. 'Smokestack nostalgia,' 'ruin porn' or working-class obituary: the role and meaning of deindustrial representation. International Labor and Working-Class History 84: 23-37.

Szolucha, A. 2018. Anticipating fracking: shale gas developments and the politics of time in Lancashire, UK. The Extractive Industries and Society 5(3): 348-355.

Threadgold, S., D. Farrugia, H. Askland, M. Askew, J. Hanley, M. Sherval and J. Coffey. 2018. Affect, risk and local politics of knowledge: changing land use in Narrabri, NSW. Environmental Sociology 4(4): 393-404.

Turner, B.S. 1987. A note on nostalgia. Theory, Culture and Society 4(1): 147-156.

U.S. Census Bureau. 2018. Annual estimates of the resident population for Ely, MN.

U.S. EPA. 2015. Superfund financial responsibility. September 28. https://www.epa.gov/superfund/superfundfinancial-responsibility

Weszkalnys, G. 2014. Anticipating oil: the temporal politics of a disaster yet to come. The Sociological Review 62: 211-235.

Weszkalnys, G. 2016. A doubtful hope: resource affect in a future oil economy. Journal of the Royal Anthropological Institute 22: 127-146.

Wheeler, R. 2014. Mining memories in a rural community: landscape, temporality and place identity. Journal of Rural Studies 36: 22-32.

Wheeler, R. 2017. Local history as productive nostalgia? Change, continuity and sense of place in rural England. Social and Cultural Geography 18(4): 466-486.

White, J. 2017. Climate change and the generational timescape. The Sociological Review 65(4): 763-778. 